\title{
SALIVA AS A DIAGNOSTIC FLUID
}

\author{
Pezelj-Ribaric Sonja, Prpic Jelena, Glazar Irena
}

Department of Oral Medicine and Periodontology, Clinical Hospital Centre, Faculty of Medicine, University of Rijeka, Croatia

Primljen/Received 31. 08. 2015. god.

Abstract: Saliva is a readily available oral fluid with many functions, from digestion, maintenance of oral tissues' integrity, to caries prevention. Changes regarding its secretion may be divided into qualitative and quantitative: both of them are a consequence of certain conditions/diseases (e.g. internal factors) or nutrients/drugs ingested (e.g. external factors). During the last 15 years, technological advances gave a significant momentum to utilization of saliva as a diagnostic tool. Analysis of saliva, just like the blood analysis, has two main objectives: to identify the subjects suffering from a certain disorder, and to follow the development and progress of therapy. This paper provides an overview of possibilities for the use of saliva for diagnostic purposes and gives specific examples of some clinical investigations, with the final aim to stimulate the use of this noninvasive means for the health care promotion.

Key words: caries, diagnosis, disease, oral fluid, saliva.

\section{INTRODUCTION}

Saliva is a complex fluid originating from three major and several minor salivary glands, gingival crevicular fluid, bacterial products, epithelial cells and food debris (1). In addition, it contains minerals, electrolytes, buffers, enzymes and their inhibitors, growth factors, cytokines, immunoglobulins, mucin, and other glycoproteins $(2,3)$. About $93 \%$ of its volume is secreted by major salivary glands, while the remaining $7 \%$ originates from minor salivary glands. The main component of the saliva is water - $99 \%$. Secretion of the saliva may be influenced by numerous physiological and pathological factors, either reversibly or irreversibly. Saliva plays an important role in maintaining the integrity of oral cavity, as well as digestion and control of oral infections (4). The role of saliva in caries protection may be viewed from 4 aspects: dilution and elimination of sugars and other compounds, buffering action, balance between demineralization and reminera-
Prihvaćen/Accepted 31. 10. 2015. god.

lization process, and antimicrobial function. Saliva may present an option for diagnostics of specific disorders and diseases. Finally, it enables tracking of disease pathogenesis. Although the main component of the saliva is water, it plays an important role in lubrication and reparation of oral mucosa, formation and swallowing of the food bolus, and control of the oropharyngeal microbial population.

\section{CLINICAL IMPORTANCE OF QUALITY AND QUANTITY OF SALIVA IN ORAL HEALTH MAINTENANCE}

Just as much as the quantity, the quality of saliva holds a great importance since every single component plays a role in its various specific functions. Normal quantity of saliva may be reduced significantly affecting the individual quality of life and oral health. Leading signs and symptoms related to hyposalivation are "dry mouth syndrome" or xerostomia, thirst, difficulty swallowing and chewing, especially when eating dry foods, a need to sip drinks frequently, difficulty wearing dentures, mouth soreness and irritation, and burning mouth sensation.

Reduced salivary flow may be caused by many physiological and pathological mechanisms.

Salivary gland function is naturally reduced in elders. Furthermore, decreased secretion is related to the intake of certain medications, diabetes and hypertension. More than 400 commonly prescribed drugs may affect salivary secretion. Head and neck radiotherapy cause irreversible destruction of the glandular parenchyma. Certain systemic disorders, such as some autoimmune disorders (namely Sjögren syndrome) lead to a progressive destruction of salivary glands, while others cause vascular or neurological alterations showing short or long- term repercussions on salivary secretion: these include hypertension, depression, malnourishment, dehydration and diabetes. 
Salivary secretion has its physiological peak in the time of tooth eruption and is related to hyperstimulation of peripheral receptors in oral mucosa. This hyperstimulation may also be observed during the first trimester of pregnancy and menstrual bleeding.

Pathological causes of hypersalivation are divided into oral and non-oral. The former include the initial stages of prosthetic rehabilitation with a denture, toothache, irritation and/or pain in the oropharyngeal region. On the other hand, certain neurological disorders such as Parkinson's disease, epilepsy, encephalitis, or some tumors, as well as exogenous toxins (bismuth, mercury, silver, gold, arsenic or endotoxins during uremia) and pilocarpine may trigger hypersalivation.

During the last 15 years, technological advances gave a significant momentum to utilization of saliva as a diagnostic tool. Measurement and tracking of the molecular components within the saliva, and their comparison to the components of the serum enabled the analysis of microorganism, chemical and immunological markers $(5,6)$. Consequently, saliva became not just an indicator of oral health but also a powerful tool for measuring basic indicators of overall health. Nowadays, there is a growing interest for investigations regarding the use of saliva for diagnostic purposes. Analysis of saliva, just like the blood analysis, has two main objectives: to identify the subjects suffering from a certain disease, and to follow the development and progress of therapy. Advantages of using the saliva as a diagnostic medium compared to the blood are simple and non-invasive sampling procedure (devoid of stress or risks) easily acceptable for the patient, low cost, and use for investigation purposes. One of the most important advantages for using the saliva as a diagnostic tool is its simple, non-invasive sampling process.

Various components within the saliva, besides protecting tissue integrity, enable detection of local and systemic conditions and diseases. Saliva is especially useful for qualitative diagnostics and detection of certain markers in numerous diseases, such as viral infections (HIV, hepatitis), some hereditary diseases (cystic fibrosis), autoimmune disorders (Sjögren syndrome), and malignancies. For example, p53 is known as a tumor suppressor protein and antibodies targeted against it have been detected in patients with squamous cellular carcinoma in the oral cavity, thus helping the early detection and monitoring of this disease $(7,8)$.

There are several reports describing possible uses of salivary creatinine levels in detection of renal diseases $(9,10,11)$.

Saliva also represents a useful medium for diagnosis of certain oral diseases, and monitoring of drug and hormone levels. Specific salivary tests for antibodies (anti-viral and anti-bacterial), steroid hormones (es- trogen, progesterone and testosterone), exogenous toxins (cadmium and mercury), tobacco and some drugs (ethanol, lithium) have a sufficient sensitivity to reflect their blood levels (12). Qualitative changes in its composition provide necessary information related to diagnostics of certain oral diseases. Namely, increased albumin levels in whole saliva were demonstrated in patients on chemotherapy who developed stomatitis later on, posing as a significant marker for future prognosis of this complication (13). Increased levels of salivary nitrates and nitrites, and reduced activity of nitrate reductase were detected in patients with oral carcinoma when compared to healthy subjects.

Detection of increased numbers of certain bacterial species in the saliva is related to increased possibility of caries development, especially on the root surface (4).

Saliva may be collected with or without stimulation; one of the best methods for unstimulated saliva collection is passive drool into the measuring sterile vial (14). Collection of stimulated saliva is performed following chewing or stimulation of taste buds.

One of the most common methods used in research is collection of the whole unstimulated saliva (WUS) which represents the pool of saliva from all major and minor- salivary glands.

Although WUS represents both local and systemic pathophysiological states in the moment of saliva collection, some factors such as hyposalivation in elders, use of certain drugs, periodontitis, fear and anxiety may affect the results obtained during such research.

Due to the relationship between oral and overall health, clinicians mostly use saliva as diagnostic means, although it is still debated that we could profit even more from such analyses $(15,16)$.

In the past, mostly used diagnostic means was blood serum, however saliva holds many advantages over both serum and urine (2).

Saliva is readily collected during clinical or laboratory work in quantities sufficient for various tests. These tests hold certain advantages over serum analysis since saliva collection is non-invasive, therefore preventing fear, uneasiness and anxiety which patients feel when involved in other analyses.

Cytokines play role in pathogenesis of numerous oral diseases such as bacterial, viral and fungal infections, as well during the pathogenesis of immunological disorders of the oral cavity and development of precancerous lesions.

Research demonstrated a significant increase in the levels of interleukin-6 (IL-6) and interleukin-2 (IL-2) in the saliva of patients with Sjögren syndrome and decreased levels of IL-2 in patients under treatment with pilocarpine (17). 
Saliva of HIV-positive patients with oral candidiasis holds elevated values of interferon gamma (IFN- $\gamma$ ) compared to other HIV-positive patients with healthy mouth and otherwise healthy controls. In addition, increased values of IFN- $\gamma$ were found in saliva of HIV-positive patients with oral villous leukoplakia, compared to HIV-positive patients without pathological oral findings (18).

Saliva of patients suffering from recurrent aphthous ulcerations which developed as a consequence of destructive autoimmune reaction reportedly has decreased values of vascular endothelial growth factor (VEGF) - the cytokine which plays a role in angiogenesis and healing (19).

In our previous researches we predominantly used saliva for the purpose of cytokine detection in particular oral diseases. In patients with oral lichen planus (OLP), we tested the levels of salivary tumor necrosis factor-alpha (TNF- $\alpha$ ). This study was undertaken to quantify the salivary levels of pro-inflammatory marker in the reticular and the erosive/atrophic forms of OLP, compared with age-matched healthy control volunteers. Whole saliva from 40 patients with active lesions of OLP, as well as from 20 healthy persons, was investigated for the presence of TNF- $\alpha$ by enzyme immunoassay. Salivary TNF- $\alpha$ levels were significantly increased in patients with OLP in comparison with healthy subjects. The presence of TNF- $\alpha$ showed positive correlation to clinical forms of OLP, being significantly higher in the erosive/atrophic type than in the reticular type of disease. Saliva provides an ideal medium for the detection of pro-inflammatory markers of the oral cavity. In patients with OLP, TNF- $\alpha$ levels in saliva were elevated, correlating with the severity of illness. Salivary TNF- $\alpha$ analysis may be a useful diagnostic tool and a potential prognostic marker in OLP (20).

Since burning mouth syndrome (BMS) is quite common diagnosis in the field of oral medicine, and taking into account painful symptoms in many patients who do not express any clinical changes on the oral mucosa, we have undertaken a study focusing on salivary levels of IL-2 and IL-6. Affected patients often presented multiple oral complaints, including burning, dryness, and taste alterations. The etiology of BMS is still unknown. Role of various cytokines has been implicated in the development of BMS. The aim of this study was to evaluate levels of salivary IL-2 and IL-6 in patients with BMS, compared with age-matched healthy volunteers (control group). Whole saliva from 30 patients with BMS, age range 555 , was tested for the presence of IL- 2 and IL- 6 by enzyme immunoassay. Control group consisted of 30 healthy participants, aged 555 years. Saliva IL-2 concentrations in BMS were significantly increased in patients compared to healthy subjects: mean 34.19 .7 versus $7.33 .0 \mathrm{pg} / \mathrm{mL}$; $\mathrm{P}<.001$. Patients with BMS had significantly higher concentrations of IL-6 compared to control: mean 30.8 5.6 versus $5.22 .8 \mathrm{pg} / \mathrm{mL} ; \mathrm{P}<.001$. In patients with BMS, IL-2 and IL-6 levels in saliva were elevated, correlating with the severity of illness (21).

In yet another study we compared the levels of proinflammatory cytokines in patients with burning mouth syndrome before and after low level laser therapy (LLLT) (22). The aim of this study was to determine the levels of proinflammatory cytokines TNF- $\alpha$ and IL-6 in WUS in subjects with BMS before and after treatment with LLLT. BMS is characterized by a continuous, painful burning sensation in a clinically normal-appearing oral mucosa. A sample consisting of 40 consecutive subjects was selected on a voluntary basis from the pool of patients who presented for diagnosis and treatment of BMS. For determination of salivary levels of TNF- $\alpha$ and IL-6, an enzyme-linked immunosorbent assay (ELISA) was performed. After 4 weeks of LLLT, the salivary levels of TNF- $\alpha$ and IL-6 in the experimental group decreased significantly $(\mathrm{p}<0.001)$. There was no significant difference in the experimental group regarding visual analogue scale.

Regarding quite frequent questions on negative effects of amalgam fillings and their possible influence on pathological changes on the oral mucosa, we ran a research on correlation between oral lichenoid reaction and amalgam fillings. The aim of this study was to perform a clinical assessment of the association between oral lichenoid reactions (OLR) and amalgam restorations and to determine the salivary concentrations of IL-6 and IL- 8 before and after replacement of the amalgam restorations. The study included 20 patients with OLR and 20 healthy volunteers. All patients were skin patch tested by an experienced physician. Saliva samples were collected, prepared and analyzed for IL-6 and IL-8 concentrations using enzyme-linked immunosorbent assay. Sixteen out of 20 patch-tested patients showed a sensitization to inorganic mercury or amalgam. Total replacement of all amalgam fillings was carried out on 20 patients with fillings based on composite resin, gold, porcelain or a combination of these. Sixteen out of 20 patients showed complete healing of OLR; three patients had marked improvement, whereas one patient showed no improvement. Levels of IL-6 detected before replacement were significantly higher than IL-6 levels following the replacement $(\mathrm{P}=0.003)$. The IL-8 levels measured before replacement procedure were significantly higher than the IL-8 levels after replacement of the fillings $(\mathrm{P}<0.001)$. On the basis of clinical observations, restorative therapy resulted in tissue healing. Following the replacement of amalgam fillings with fillings based on other restorative materi- 
als, levels of both IL-6 and IL-8 shifted towards normal, as measured in healthy subjects (23).

In order to prove the efficacy of the biostimulative laser therapy, we ran a research correlating the clinical signs to biostimulative therapy and levels of TNF- $\alpha$ and IL- 6 . The aim of this study was to monitor therapeutic response by determining the levels of proinflammatory cytokines TNF- $\alpha$ and IL- 6 in whole unstimulated saliva in patients with denture stomatitis (DS), before and after laser therapy. DS is an inflammatory condition that occurs in subjects who wear dentures (usually upper), and it is a common oral mucosal lesion. A potential noninvasive treatment for DS patients is laser phothotherapy. A group of 40 consecutive subjects was selected on the voluntary basis from the pool of patients who presented for the diagnostics and treatment of DS. A clinical examination was performed according to the standard clinical criteria. Lesions described as palatal inflammation were diagnosed as Newton type II denture stomatitis. The patients were randomly assigned to either an experimental group (20 patients receiving the real LPT) or a control group (20 patients receiving inactive/placebo laser treatment). In order to determine the salivary levels of TNF-á and IL-6, ELISA testing was performed. Following treatment with LPT for 4 weeks, the levels of TNF- $\alpha$ and IL-6 decreased significantly $(p<0.001)$ and were significantly different from controls $(p<0.001)$.The results of this study suggest that LPT may be an effective choice of therapy (24).

\section{CONCLUSION}

During the past 10 years we ran several investigations where we used saliva as a diagnostic tool, and consequently we have proved that it may be regarded as the perfect medium to be explored for health and disease monitoring. The translational applications and opportunities are enormous. The ability to monitor health status, disease onset and progression, and treatment outcome through noninvasive means is the most desirable goal in the health care promotion and delivery.
Abbreviations
WUS - whole unstimulated saliva
IL-6 - interleukin-6
IL-2 - interleukin-2
IFN- $\gamma$ - interferon gamma
VEGF - vascular endothelial growth factor
OLP - oral lichen planus
TNF- $\alpha$ - tumor necrosis factor-alpha
BMS - burning mouth syndrome
LLLT - low level laser therapy
OLR - oral lichenoid reactions
DS - denture stomatitis
LPT - laser phototherapy laser phototherapy

\title{
Sažetak
}

\section{SALIVA KAO DIJAGNOSTIČKI MATERIJAL}

\section{Pezelj-Ribaric Sonja, Prpic Jelena, Glazar Irena}

\author{
Department of Oral Medicine and Periodontology, Clinical Hospital Centre, Faculty of Medicine, University of Rijeka, Croatia
}

Pljuvačka je dostupna oralna tečnost sa brojnim funkcijama, od varenja, preko održavanja integriteta tkiva, do prevencije karijesa. Promene koje se odnose na sekreciju pljuvačke mogu biti kvalitativne i kvantitativne: obe promene su posledica određenih stanja/bolesti (unutrašnjih faktora) ili hranljivih materija/lekova unetih u organizam (spoljašnji faktori). U poslednjih 15 godina, napreci u oblasti tehnologije dali su veliki doprinos korišće-

\section{REFERENCES}

1. Farnaud SJ, Kosti O, Getting SJ, Renshaw D. Saliva: physiology and diagnostic potential in health and disease. ScientificWorldJournal. 2010; 10: 4346.

2. Malamud D, Tabak LA, editors. Saliva as a Diagnostic Fluid: Ann NY Acad Sci. 1992. Malamud D, Tabak LA, eds. Saliva as a Diagnostic Fluid; No. 694. nju pljuvačke u dijagnostičke svrhe. Analiza pljuvačke, kao i analiza krvi, ima dva glavna cilja: da identifikuje supstance organizma koji trpe zbog određene bolesti, i da prate napredak i terapijski učinak. Ovaj rad obezbeđuje pregled mogućnosti koje pruža korišćenje salive u dijagnostičke svrhe i daje primere određenih kliničkih istraživanja, sa glavnim ciljem da stimuliše korišćenje ovog neinvazivnog sredstva u unapređenju zdravlja populacije.

3. Malamud D, Niedbala RS. Oral-based diagnostics. 1st ed. Boston: Mass; 2007.

4. Corstjens PLAMMD. Point-of-care Diagnostics for infectious diseases. In: Wong DT, editor. Saliva Diagnostics. Ames: Wiley-Blackwell; 2008. p. 2434

5. Wen ZT, Yates D, Ahn SJ, Burne RA. Biofilm formation and virulence expression by Streptococcus mutans are altered when grown in dual-species model. BMC Microbiol. 2010; 10: 111. 
6. Goncalves Lda R, Soares MR, Nogueira FC, et al. Comparative proteomic analysis of whole saliva from chronic periodontitis patients. J Proteomics. 2010;73 (7): 13341.

7. Parisi MR, Soldini L, Di Perri G, Tiberi S, Lazzarin A, Lillo FB.Offer of rapid testing and alternative biological samples as practical tools to implement HIV screening programs. New Microbiol. 2009; 32(4): 391.

8. White DA, Scribner AN, Huang JV. A comparison of patient acceptance of fingerstick whole blood and oral fluid rapid HIV screening in an emergency department. J Acquir Immune Defic Syndr. 2009; 52(1): 75 .

9. Arregger AL, Cardoso EM, Tumilasci O, Contreras LN. Diagnostic value of salivary cortisol in end stage renal disease. Steroids. 2008; 73(1): 772.

10. Nagler RM. Saliva analysis for monitoring dialysis and renal function. Clin Chem. 2008; 54(9): 1415 .

11. Savica V, Calo L, Santoro D, Monardo P, Granata A, Bellinghieri G. Salivary phosphate secretion in chronic kidney disease. J Ren Nutr. 2008; 18(1): 870.

12. Bilodeau E, Alawi F, Costello BJ, Prasad JL. Molecular diagnostics for head and neck pathology. Oral Maxillofac Surg Clin North Am. 2010; 22(1): 183-94.

13. Hu S, Arellano M, Boontheung P, et al. Salivary proteomics for oral cancer biomarker discovery. Clin Cancer Res. 2008; 14(19): 6246-52.

14. Navazesh M. Methods for collecting saliva. Ann NY Acad Sci. 1993; 694: 72-7.

15. Kaufman E, Lamster IB The diagnostic applications of saliva-a review. Crit Rev Oral Biol Med. 2002; 13(2): 197-212.

16. Tavassoli M, Brunel N, Maher R, Johnson NW, Soussi T. P53 antibodies in the saliva of patients with squamous cell carcinoma of the oral cavity. Int J Cancer. 1998; 78(3): 390-1.
17. Rhodus NL, Dahmer L, Lindermann K, Rudney J, Mathur A, Bereuter J. s-IgA and cytokine levels in whole saliva of Sjogren's syndrome patients before and after oral pilocarpine hydrochloride administration: a pilot study. Clin Oral Investig. 1998; 2(4): 191-6.

18. Black KP, Merill KW, Jackson S, Katz J. Cytokine profiles in parotid saliva from HIV-1 infected individuales: changes associated with opportunistic infections in the oral cavity. Oral Microbiol Immunol. 2000; 15(2): 74-81.

19. Brozović S,Vučićević-Boras V, Mravak-Stipetić M, Jukic S, Kleinheinz J, Lukac J. Salivary levels of vascular endothelial growth factor(VGEF) in recurrent aphthous ulceration. J Oral Pathol Med. 2002; 31(2): 106-8.

20. Pezelj-Ribaric S, Prso IB, Abram M, Glazar I, Brumini G, Simunovic-Soskic M. Salivary levels of tumor necros factor-alpha in oral lihen planus. Mediators Inflamm. 2004; 13(2): 131-3.

21. Simčić D, Pezelj-Ribarić S, Grzić R, Horvat J, Brumini G, Muhvić-Urek M. Detection of salivary interleukin 2 and interleukin 6 in patients with burning mouth syndrome. Mediators Inflamm. 2006; 2006(1): 54632.

22. Pezelj-Ribarić S, Kqiku L, Brumini G, et al. Proinflammatory cytokine levels in saliva in patients with burning mouth syndrome before and after treatment with low level laser therapy. Lasers Med Sci. 2013; 28(1): 297-301.

23. Pezelj-Ribarić S, Prpić J, Miletić I, Brumini G, Soskić MS, Anić I. Association between oral lichenoid reactions and amalgam restorations. J Eur Acad Dermatol Venereol. 2008; 22(10): 1163-7.

24. Šimunović Šoškić M, Pezelj-Ribarić S, Brumini G, Glazar I, Grzić R, Miletić I. Salivary levels of TNF-alpha and IL-6 in patents with denture stomatitis before and after low-level laser therapy. Photomed Laser Surg. 2010; 28(2): 189-93.

\author{
Correspondence to /Autor za korespondenciju \\ Sonja Pezelj-Ribarić, PhD, DMD, Professor \\ Department of Oral Medicine and Periodontology, \\ Clinical Hospital Centre, Faculty of Medicine, \\ University of Rijeka, Croatia, \\ Krešimirova 40, Rijeka HR-51000, Croatia, \\ Tel: ++38551345634; \\ Fax: ++38551345630 ; \\ Emal: sonja.pezelj.ribaric@medri.uniri.hr
}

